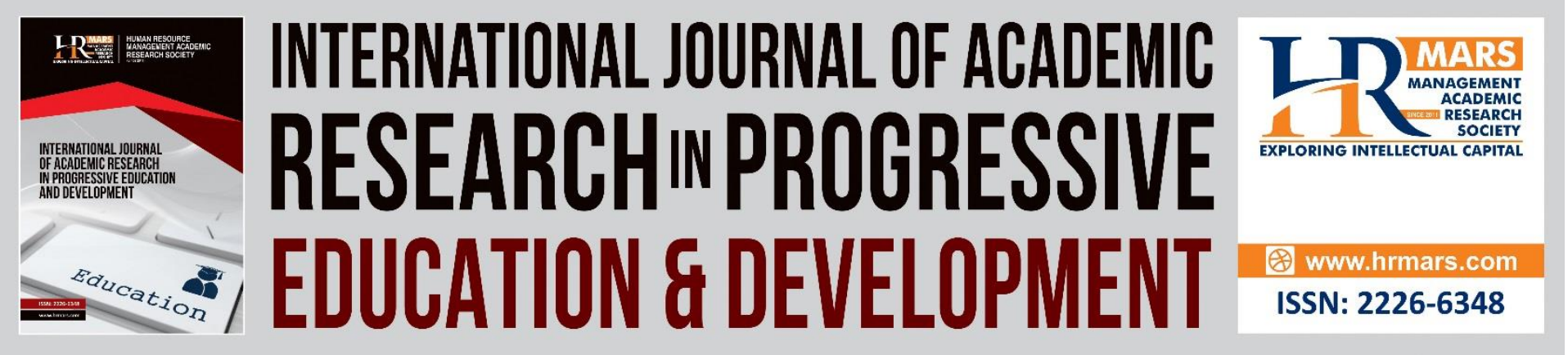

\title{
The Influence of Gender Factors on Cyber Bullying Behavior in Social Media
}

Ahmad Faqih Ibrahim, Khairul Azhar Meerangani, Muhammad Yasin Omar Mukhtar, Mohammad Fahmi Abdul Hamid, Mohamad Pirdaus Yusoh, Mohamad Firdaus Mohd Isa

To Link this Article: http://dx.doi.org/10.6007/IJARPED/v11-i1/12028

DOI:10.6007/IJARPED/v11-i1/12028

Received: 03 November 2021, Revised: 06 December 2021, Accepted: 30 December 2021

Published Online: 14 January 2022

In-Text Citation: (Ibrahim et al., 2022)

To Cite this Article: Ibrahim, A. F., Meerangani, K. A., Mukhtar, M. Y. O., Hamid, M. F. A., Yusoh, M. P., \& Isa, M. F. M. (2022). The Influence of Gender Factors on Cyber Bullying Behavior in Social Media. International Journal of Academic Research in Progressive Education and Development, 11(1), 283-294.

Copyright: (C) 2022 The Author(s)

Published by Human Resource Management Academic Research Society (www.hrmars.com)

This article is published under the Creative Commons Attribution (CC BY 4.0) license. Anyone may reproduce, distribute, translate and create derivative works of this article (for both commercial and non-commercial purposes), subject to full attribution to the original publication and authors. The full terms of this license may be seen at: http://creativecommons.org/licences/by/4.0/legalcode

Vol. 11(1) 2022, Pg. $283-294$

http://hrmars.com/index.php/pages/detail/IJARPED

JOURNAL HOMEPAGE

Full Terms \& Conditions of access and use can be found at http://hrmars.com/index.php/pages/detail/publication-ethics 


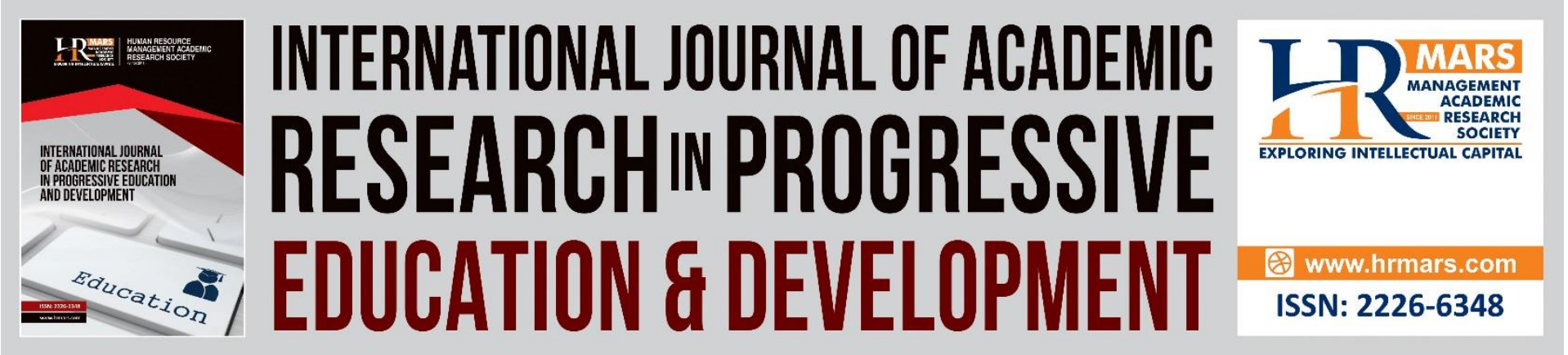

\title{
The Influence of Gender Factors on Cyber Bullying Behavior in Social Media
}

\author{
Ahmad Faqih Ibrahim \\ Faculty of Islamic Knowledge, University College of Islam Malacca
}

Khairul Azhar Meerangani

Academy of Contemporary Islamic Studies, Universiti Teknologi MARA Cawangan Melaka

Muhammad Yasin Omar Mukhtar

Unit of Research, Consultation and Innovation, University College of Islam Malacca

Mohammad Fahmi Abdul Hamid

Academy of Contemporary Islamic Studies, Universiti Teknologi MARA Cawangan Melaka

Mohamad Pirdaus Yusoh

Center for Fundamental and Continuing Education, Universiti Malaysia Terengganu

Mohamad Firdaus Mohd Isa

Sekolah Kebangsaan Bukit Piatu, Bentong, Pahang

\begin{abstract}
Malaysia is the 9th country to record the most active use of social media in the world, which is almost $80 \%$ of its total population. The explosion of information and communication technology (ICT) has greatly facilitated the life of society. However, there are a handful of parties who misuse cyber platforms for criminal purposes such as cyber bullying. Cyber bullying is increasingly becoming a culture among netizens by making an individual as a source of jokes aimed at gaining attention and pleasure on social media. On that basis, the government has introduced the Communications and Multimedia Act 1998 to monitor offenses that exist on social media, especially involving digital communications. Thus, this study aims to analyze the influence of gender factors on cyber bullying behavior in social media. The study was conducted quantitatively using a survey design. A set of questionnaires was distributed to 436 respondents in Melaka via Google Form, and then analyzed through SPSS software. The T-Test concluded significant differences in the mean scores of cyberbullying behaviors based on gender among the respondents. The mean value for males is 2.08 while the mean value for females is 1.64. $(F=4,628) ;(p<0.05)$. Thus, all parties need
\end{abstract}


to work together to create a safe and harmonious digital ecosystem, while having self -control in social interaction, especially in cyber platforms.

Keywords: Gender, Internet, Cyber Bullying, Digital Media, Communication

\section{Introduction}

The Industrial Revolution 4.0 has contributed to the rapid development in information and communication technology. To ensure that Malaysia does not lag behind in this development, the government has planned the Comprehensive Roadmap for the Industrial Revolution 4.0 (IR 4.0) and National Digital to ensure that the implementation of digital infrastructure in the country can benefit all citizens, thereby driving Malaysia's economic growth. This direction will focus on six key components namely digital talent development, new technologies, the economy of all, society and government-related. In addition, the government under the 12th Malaysia Plan (2021-2025), is also committed in the effort of improving the country's digital communications through the implementation of the digital infrastructure plan, known as the National Digital Network (JENDELA). The plan is an important platform in providing comprehensive and high-quality broadband service coverage, thus preparing the country for a steady transition to $5 \mathrm{G}$ technology. The government has also injected additional investment worth RM400 million through the Prihatin Rakyat Economic Stimulus Package (PRIHATIN) to enable the telecommunications industry to strengthen the performance of the respective network providers. Thus, all parties including state governments, local authorities, ministries and relevant agencies have been mobilized to support the government's aspiration to make communication services as a basic facility to drive the country towards a digital economy.

At the same time, the Coronavirus Infectious Disease 2019 (COVID-19) epidemic that was first detected in Wuhan, China at the end of 2019, spread so rapidly into a pandemic that change domestic and international landscape. As of September 2020, nearly 30 million people worldwide have been confirmed positive COVID-19 virus with death toll reaching 1 million people. Malaysia is one of the countries affected by the outbreak, although it started a little slow in the initial stage, which is only around 22 cases in January 2020. However, the emergence of 'Sri Petaling Cluster' detected on March 11, 2020 following a gathering of tabligh congregation at the Sri Petaling Mosque, saw a sharp increase in the number of individuals who were tested positive COVID-19, reaching three figures per day. This development has caused the government to enforce the Movement Control Order (MCO) in stages, starting MCO Phase 1 (18-31 March 2020), MCO Phase 2 (01-14 April 2020), MCO Phase 3 (15-28 April 2020) and MCO Phase 4 (April 29-May 12, 2020). During this period, the government itself has enforced various Standard Operating Procedures (SOP) including the control of movement and activities as well as the closure of risky sectors to protect Malaysians, especially from the threat of this pandemic. As a result, a successful decrease in cases was recorded enables the Movement Control Order (MCO) to be replaced with the Conditional Movement Control Order (CMCO) and subsequently the Rehabilitation Movement Control Order (RMCO).

Nevertheless, the MCO introduced since 18 March 2020 has indirectly introduced Malaysians to a new norm, including the use of social media and online applications for various purposes and needs. The Malaysian Communications and Multimedia Commission (MCMC) reported a sharp increase in demand for broadband since the implementation of the MCO as business activities, learning, conferences, meetings and others were conducted from home. Compliance with the implemented MCO saw an increase of $23.5 \%$ in internet traffic flow nationwide in the first week of $\mathrm{MCO}$, and further increased by $8.6 \%$ in the second week 
(MCMC, 2020). The explosion of information and communication technology (ICT) has greatly facilitated the life of society. Many affairs and services can be accessed and managed online quickly. However, not all users are able to take the advantage of the development which resulting from the advancement of information and communication technology very well. Some of them were detected to have abused the cyber medium as a platform to commit crimes and make easy profits, leading to an increasingly serious problem of cyber crime. According to the Deputy Minister of Communications and Multimedia, Datuk Zahidi Zainul Abidin, cyber crime complaints were reported to increase by $91.37 \%$ during MCO from March 18 to June 30, 2020, compared to cases reported in 2019. According to him, among the cyber crimes that received the highest complaints was cyber bullying, fraud, data theft and hacking especially in urban areas with high internet access speeds (RTM, 2020). Thus, swift and collective action has been taken by the authorities, especially involving MCMC, Cyber Security and PDRM to prevent these criminal activities from spreading, thereby protecting users of social media and online applications from being caught with such crimes.

\section{Use of Social Media in Malaysia}

The Industrial Revolution 4.0 has brought great changes in the digital world. The development of the digital world led by information and communication technology is increasingly sophisticated. It also has a great impact on the pattern of social interaction in society. In the interactions that take place today, consumer networks have crossed national, religious and racial boundaries. They can communicate quickly, cheaply and easily without any limits. Based on global internet usage statistics, a total of 26.4 million people out of Malaysia's 32.68 million population were internet users in the second quarter of 2019. Internet usage is more focused on new social media such as Facebook, Twitter, Instagram and Whatsapp. Nevertheless, lately we are presented with a variety of unhealthy symptoms that occur among citizens of the digital world, involving abuse in social media. These include spying and cyberbullying, spreading slander and false news, making uncivilized comments and hate speech, in addition to blowing up racist and religious sentiments.

The use of social media and online applications in Malaysia is regulated by the Malaysian Communications and Multimedia Commission (MCMC). The role of MCMC is to implement and to enforce the preparation of communication and multimedia laws, regulate all matters related to communication and multimedia activities, control and monitor communication and multimedia activities and take action on every complaint related to communication and multimedia. Based on the report, a total of 11,235 complaints related to new media were recorded during January-June 2020, covering hacking activities, online gambling, promotion of prostitution, copyright infringement, forgery, pornography, sedition and so on. Of the total, a total of 11,216 or $99.83 \%$ complaints were successfully handled, namely $80.56 \%$ complaints that have been given advice, guidance and education to the community, $18 \%$ complaints that have been referred to social media platform providers for further action based on terms and conditions, and $1.27 \%$ found to be in violation of the provisions under Section 233 of the Communications and Multimedia Act (CMA) 1998 (MCMC, 2020). In general, cases of online fraud, cyber bullying as well as false and seditious news were seen to dominate cyber crime throughout the MCO which saw an increase in complaints related to these three forms of crime.

The era of globalization has seen an increase in the sophistication of technology today especially involving cyber mediums. The growing trend of borderless communication has seen the increase of ICT technologies usage such as computers and mobile phones. Although the 
existence of this limitless world is able to provide a positive impact, but at the same time there are also negative effects that were produced such as symptoms of cyber bullying. Cyberbullying is defined as the use of technology-based communications including cellular phones, emails, instant messaging and social networks aimed at inciting harassment or intimidation against individuals through online messages or expressions (Hasniza et al., 2018). More worryingly, these symptoms are increasing and evolving in various forms thus inviting warnings from the authorities. The implementation of MCO has indirectly exacerbated these symptoms due to the factors of a lot of free time and stress experienced while at home (Basir et al., 2020). The annoyance of facing the new norm throughout the COVID-19 threat should not be misused for the dissemination of unauthentic information so as to provoke panic among the general public. The threat of a pandemic should be taken seriously, rather than being used as entertainment material and causing public outrage. The public also needs to be more careful in receiving and disseminating any information, especially those whose truth status is still in doubt (Anuar et al., 2018). Any information related to COVID-19 can be obtained through the official portal of the Ministry of Health Malaysia (MOH) or the World Health Organization (WHO). Apart from that, the MCMC also provides information review facilities through the Sebenarnya.my portal as a platform for the public to identify the status of information that is hovering on social media.

However, in the first 6 months of 2020, cases related to the spread of false news were seen to take place more than sedition offenses. The community's experience in facing the threat of the COVID-19 epidemic to the point of triggering new norms has caused new excitement on social media, especially by sharing and spreading false news related to the Movement Control Order (MCO), Bantuan Prihatin Nasional (BPN), assistance from the Social Welfare Department (JKM) and matters relating to the COVID-19 pandemic. Access to more information that is online has led to a dumping of public data information on social media. The culture of spreading fake news only creates negative cognitive in society thus giving rise to panic, excitement and emotional play which eventually leads to a negative atmosphere (Basir et.al, 2020). According to the Chief Executive Officer of Cyber Security Malaysia (CSM), Datuk Dr Amirudin Abdul Wahab, the community needs to be more sensitive and prepared for the increasingly serious threat of cyber bullying as it is more dangerous than physical bullying. These symptoms of cyber bullying can be done by anyone without control because it involves cyber medium. The identity of the bully is also sometimes difficult to identify because the internet provides an 'anonymity' setting. In addition, access to the content of the bullying is also always repeated because the material remains in the cyber medium as long as it is not deleted by the bully. This causes some victims of bullying to face stress and in some cases gives rise to the victim's desire to commit suicide (Hasniza et.al, 2018).

The Malaysian Youth Development Research Institute (IPPBM) in 2017 conducted a study on 1382 youths aged 15 to 30 years old consisting of 6 different zones, namely the Northern Zone, East Zone, Central Zone, Southern Zone, Sabah and Sarawak. This study was conducted to analyze the phenomenon of cyber bullying among youth in Malaysia. The results showed that the majority of youths were involved as victims of cyber bullying, which was $62.3 \%$, with $1.21 \%$ of them facing emotional stress to the point of attempting suicide (IPPBM, 2017). Based on this study, the group most exposed to the symptoms of cyber bullying are women which is $58.19 \%$ compared to men which is only $41.81 \%$. A study by the United Nations Children's Fund (UNICEF) and the MyHealth Malaysia portal on more than 5,000 respondents revealed that 3 out of 10 young people in Malaysia are victims of cyber bullying, thus affecting their education and social life (Maria, 2019). The rapid advancement of 
information and communication technology in line with the era of the Industrial Revolution 4.0 has made everything at your fingertips. Although many benefits are obtained as a result of this development, but in other aspects such as privacy and security of each cyber medium user also need to be given primary attention (Windarsih \& Choiriyati, 2019). The sophistication of technology should not erode the human value of every user so that it is used as an instrument to manipulate and encroach on the rights of their fellow human beings. In fact, the ethical use of social media and online applications is able to make the cyber medium as a new platform that is useful in carrying out various activities and current needs.

\section{Methodology}

The study was conducted quantitatively using a survey design. A set of questionnaires was handed over to selected respondents to obtain the data required in the study. The selected study sample is social media users among female youth in Melaka. Based on Krejci and Morgan's (1970) table, the estimated sample size is 400 people. However, after the evaluation, a total of 436 respondents were listed as the study sample. The selection of the study sample uses purposive sampling technique where the sample consists of a specific and specific sample and coincides with the objectives of the study. Respondent profile information was obtained from the feedback contained in the questionnaire that was distributed to all respondents via google form. The description process focuses on the demographic factors of the respondents, namely age, social media platform, time period and purpose of surfing the internet. To test the validity and reliability of the items in the selected questionnaires before the actual study was conducted, a pilot study was conducted first to identify the overall appropriateness of the instrument's use to the study respondents, especially involving the use of terminology and sentence structure. Respondents for this pilot study were selected at simple random consisting of 30 social media users among female youth in Melaka. The findings of the pilot study are as follows:

\begin{tabular}{|l|l|}
\hline $\begin{array}{l}\text { Cronbach's } \\
\text { Alpha }\end{array}$ & N of Items \\
\hline .753 & 24 \\
\hline
\end{tabular}

Table 1: Reliability Statistics

Based on Table 1 above, Cronbach's Alpha for all items was .753 with 24 items measured and acceptable. According to Sproles and Kendall (1986), Cronbach's Alpha is a measure of internal consistency, i.e. the extent to which it relates to a set of items as a group. It is considered a measure of scale reliability in factors where Cronbach's Alpha coefficient at 0.4 or higher is considered acceptable. Therefore, we can conclude that Cronbach's Alpha for all variables in this study is considered acceptable. Once the data through the questionnaire method has been collected and keyed-in in the form provided in the SPSS program, it will be analyzed and presented in the form of descriptive statistics (Zulkarnain \& Hishamuddin, 2001). According to Baba (1997), descriptive statistics are used to describe the state of the data found in the study sample. It is the process of collecting data, making conclusions and presenting conclusions and forms that are easy to understand by the target group. With this SPSS method, a researcher can make estimates about the mean (mean), standard deviation, variance and others for a variable (Mahdzan, 1983). In addition, descriptive statistics aims to provide a systematic description of the facts and characteristics of a population or field of 


\section{DEVELOPMENT}

Vol. 11, No. 1, 2022, E-ISSN: 2226-6348 @ 2022 HRMARS

interest factually and accurately (Sidek, 2000). Researchers used T-Test analysis to test the hypotheses that had been constructed. The analysis was performed using Statistical Package for the Social Sciences (SPSS) software for Windows version 22.0.

\section{Finding and Discussion}

Based on the study that has been conducted, the analysis of the findings obtained has been done as follows:

a) Demographics of Respondents

Respondent profiles were formed to look at the characteristics of the respondents in this study as well as to identify and provide information about the background of the respondents. The profile of the respondents based on the questionnaire obtained is as follows:

\begin{tabular}{|l|l|l|}
\hline Type & Frequency & Percentage (\%) \\
Gender & 140 & 32.1 \\
Men & 296 & 67.9 \\
Women & & \\
Age &
\end{tabular}

\begin{tabular}{|c|c|c|}
\hline 15 to 25 years old & 214 & 72.3 \\
\hline 25 to 35 years old & 65 & 21.9 \\
\hline 35 to 45 years old & 17 & 5.8 \\
\hline \multicolumn{3}{|l|}{ Frequently Used Social Media } \\
\hline Facebook & 14 & 4.6 \\
\hline Twitter & 41 & 13.8 \\
\hline Whatsapp & 111 & 37.4 \\
\hline Telegram & 4 & 1.4 \\
\hline Instagram & 52 & 17.4 \\
\hline Youtube & 44 & 14.7 \\
\hline Tik Tok & 21 & 7.1 \\
\hline Others & 12 & 3.6 \\
\hline \multicolumn{3}{|c|}{ Purpose of Surfing the Internet } \\
\hline Play games & 12 & 4.1 \\
\hline Information/Learning & 91 & 30.7 \\
\hline Get Rid of Boredom & 104 & 35.1 \\
\hline Completing Assignments & 72 & 24.3 \\
\hline Others & 17 & 5.8 \\
\hline \multicolumn{3}{|l|}{ Internet Surfing Period } \\
\hline Below 1 hour & 2 & 0.5 \\
\hline 1 to 3 hours & 34 & 11.5 \\
\hline 4 to 6 hours & 111 & 37.4 \\
\hline 6 hours and above & 149 & 50.6 \\
\hline
\end{tabular}

Table 2: Demographics of Respondents

Table 1 shows the number and percentage of respondents by age. From the demographic analysis, a total of 140 male respondents and 296 female respondents were involved in this study. This study also involves various age groups that have been divided into 3 categories namely 15 to 25 years, 25 to 35 years and 35 to 45 years. The majority of respondents are in 
the age category of 15 to 25 years which is 214 people (72.3\%), followed by respondents aged 25 to 35 years as many as 65 people $(21.9 \%)$ and the last respondents aged 35 to 45 years which is 17 people (5.8\%). For social media that is frequently used, the majority of respondents use Whatsapp application which is 111 people (37.4\%), followed by Instagram as many as 52 people (17.4\%), Youtube 44 people (14.7\%), Twitter 41 people (13.8\%), Tik Tok 21 people (7.1\%), Facebook 14 people (4.6\%), other 12 people (3.6\%) and Telegram which is 4 people (1.4\%) For the purpose of surfing the internet, the majority of respondents are in the category of getting rid of boredom which is 104 people (35.1\%) followed by seeking information or learning a total of 91 people (30.7\%), then completed tasks a total of 72 people (24.3\%), other purposes 17 people (5.8\%) and to play games as many as 12 people $(4.1 \%)$. The last demographic analysis involves various levels of time period of surfing the internet which has been divided into 4 categories namely less than 1 hour, 1 to 3 hours, 4 to 6 hours and 6 hours and above. The majority of respondents are in the category of 6 hours and above which is 149 people (50.6\%), followed by 4 to 6 hours as many as 111 people (37.4\%), 1 to 3 hours 34 people (11.5\%) and the last respondents who surf the internet less than 1 hour for 2 people $(0.5 \%)$.

b) Descriptive Analysis

Descriptive analysis provides a summary and information on the data used in this study. This analysis was conducted to look at the involvement and exposure of respondents to the symptoms of cyber bullying in social media. 
INTERNATIONAL JOURNAL OF ACADEMIC RESEARCH IN PROGRESSIVE EDUCATION AND

DEVELOPMENT

Vol. 11, No. 1, 2022, E-ISSN: 2226-6348 @ 2022 HRMARS

\begin{tabular}{|c|c|c|c|c|c|c|}
\hline \multirow[t]{2}{*}{ No } & \multirow[t]{2}{*}{ Question } & \multicolumn{5}{|c|}{ Percentage } \\
\hline & & SD & D & $\mathbf{N}$ & A & SA \\
\hline 1 & I was once humiliated on social media & 17.8 & 31.5 & 12.4 & 21.7 & $\begin{array}{l}16 \\
6\end{array}$ \\
\hline 2 & $\begin{array}{l}\text { I have received threats and insults on } \\
\text { social media }\end{array}$ & 21.1 & 39.2 & 8.9 & 19.3 & $\begin{array}{l}11 . \\
5\end{array}$ \\
\hline 3 & $\begin{array}{l}\text { I used to make fun of any contact on } \\
\text { social media }\end{array}$ & 29.1 & 22.3 & 11.8 & 5.7 & 1.0 \\
\hline 4 & $\begin{array}{l}\text { I once received embarrassing and } \\
\text { insulting comments on social media }\end{array}$ & 49.0 & 11.8 & 5.1 & 21.6 & $\begin{array}{l}12 \\
5\end{array}$ \\
\hline 5 & $\begin{array}{l}\text { I used to spread fake news or } \\
\text { information on social media }\end{array}$ & 59.9 & 20.3 & 8.8 & 8.0 & 3.0 \\
\hline 6 & $\begin{array}{l}\text { I enjoy seeing other individuals being } \\
\text { ridiculed and bullied on social media }\end{array}$ & 82.8 & 13.9 & 2.0 & 1.4 & 0 \\
\hline 7 & $\begin{array}{l}\text { I once received sexual harassment on } \\
\text { social media }\end{array}$ & 48.0 & 14.9 & 12.2 & 14.5 & $\begin{array}{l}10 . \\
5\end{array}$ \\
\hline 8 & $\begin{array}{l}\text { My personal social media site has been } \\
\text { hacked }\end{array}$ & 53.7 & 16.2 & 9.8 & 16.2 & 4.1 \\
\hline 9 & $\begin{array}{l}\text { I once uploaded videos and other } \\
\text { individual submissions without giving } \\
\text { credit to the original owner }\end{array}$ & 62.5 & 19.3 & 14.9 & 2.7 & 0.7 \\
\hline 10 & $\begin{array}{l}\text { My appearance on social media is often } \\
\text { made into a joke }\end{array}$ & 55.9 & 24.7 & 7.4 & 10.7 & 1.4 \\
\hline 11 & $\begin{array}{l}\text { I once edited and modified pictures of } \\
\text { other individuals for prank purposes }\end{array}$ & 71.0 & 16.6 & 8.8 & 3.4 & 0.3 \\
\hline 12 & $\begin{array}{l}\text { My videos or writings on social media } \\
\text { are shared without permission }\end{array}$ & 61.8 & 18.6 & 8.8 & 7.1 & 3.7 \\
\hline 13 & $\begin{array}{l}\text { I once hacked my friend's social media } \\
\text { account for a joke }\end{array}$ & 77.7 & 16.2 & 2.0 & 4.0 & 0 \\
\hline 14 & $\begin{array}{l}\text { I enjoy attacking the social media } \\
\text { accounts of any individual linked to a } \\
\text { controversy }\end{array}$ & 59.1 & 23.5 & 1.0 & 4.0 & 2.3 \\
\hline 15 & $\begin{array}{l}\text { My personal photos were once modified } \\
\text { and disseminated as humorous material }\end{array}$ & 62.6 & 16.2 & 5.7 & 9.1 & 6.4 \\
\hline
\end{tabular}

Table 3: Descriptive Analysis for Each Question

Based on table 3, cyber bullying harassment that is seen as frequent to respondents is ever humiliated on social media which is $38.3 \%$, followed by receiving embarrassing and insulting comments by $34.1 \%$, receiving threats and insults $(30.8 \%)$, sexual harassment $(25 \%)$, personal social sites were hacked (20.3\%), personal photo modification $15.5 \%$, jokes and jokes on social media (12.1\%), and lastly videos or writings were shared without permission $(10.8 \%)$. Although on average the pattern of cyber bullying among respondents is still moderate, but it needs to be taken seriously as social media should be a safe platform for users. At the same time, the study conducted on the pattern of cyber bullying behaviour by respondents on average recorded low findings, that is, once mocked contacts by $6.7 \%$, attacked other social media user accounts (6.3\%), hacked social media accounts of contacts (4.0\%), modifying 
photos of other individuals (3.7\%), sharing videos or posting without credit to the original owner (3.4\%) and lastly having fun seeing other individuals bullied on social media (1.4\%). Thus, it can be concluded that cyber bullying behaviour is relatively low by social media users among women, instead they are more at risk of being exposed as victims of cyber bullying harassment.

c) Inferential Analysis

Inferential analysis was conducted to identify the factors of gender differences on the practice of cyber bullying among youths in Melaka. Respondents' findings were analysed using T-Test to assess whether there were significant differences for the mean of cyber bullying practices based on gender factors. Based on the T-Test analysis, the findings show that there are significant differences in the mean scores of cyber bullying practices based on gender among the respondents. The mean value for males is 2.08 while the mean value for females is 1.64 . $(F=4,628) ;(p<0.05)$ as in the table below:

\begin{tabular}{llllll}
\hline Gender & $\mathbf{N}$ & $\mathbf{M}$ & SD & $\mathbf{F}$ & $\mathbf{P}$ \\
\hline Men & 140 & 2.08 & .726 & 4.628 & .032 \\
Women & 296 & 1.64 & .586 & & \\
\hline
\end{tabular}

Table 4: T-Test Analysis of Gender Differences With Cyber Bullying Practices

Based on the table, it can be proven that gender factors have a significant effect on the practice of cyber bullying among youths in Melaka. Male respondents were seen to have a greater tendency to engage in this practice of cyber bullying than female respondents.

The use of online social medias such as Facebook, Whatsapp, and Twitter provides a space that enables easy and fast social interaction. Nevertheless, unethical use of the internet to the point of triggering addiction has the potential to cause mental illness and affect the physical health of not only an individual, but the entire society (Lanaj et al., 2014). This development also implicitly causes negative impacts on the virtual citizens, especially the misuse of facilities to conduct activities that violate the ethics of consumerism and civil law. Studies by Akbulut et. al (2010); Bauman (2013); Zhou et al (2013) found that individuals who spend more time on the internet tend to engage in cyber harassment. The findings are consistent with the media effects model, which highlights the potential of media in influencing the propensity and behaviour of an individual (Valkenburg \& Peter, 2013). Also, this is in line with the online disinhibition effect that states in the digital ecosystem, individuals in general tend to express their feelings and are free to carry out any activities without reservation (Ho \& McLeod, 2008; Suler, 2004).

Furthermore, internet users are found to experience emotional stress because of being harassed on the internet and some are concerned with the security level on the internet. The ambiguity and secrecy of the perpetrators' identity cause the internet users to feel distressed because they are unable to take appropriate protection measures (Sourander et al (2016). The negative effects that are attributed to cyberbullying include deterioration in the academic performance, loss of self-confidence, emotional instability, as well as mental and physical injuries (Patchin \& Hinduja, 2008). Therefore, everyone needs to practise selfcontrol while communicating on social media without having to encroach on the privacy and dignity of other users. Although cyber space is a borderless realm, but as a human being every user still needs to respect the rights and privacy of others in social media. Everyone is 
accountable to create a safe environment in any places by being respectful, besides always complying with the ethics in communication, anywhere the interaction takes place, be it physical or virtual. The act of harassing and encroaching on the privacy boundaries of other social media users are indeed unethical and needs to be curbed. Each party needs to know the limitations of rights and rules set by the government on the use of social media and online applications.

\section{Conclusion}

The use of social media is a major need for every society, especially in the era of the Industrial Revolution 4.0. However, its unethical use exposes the abuse of social media for purposes that violate societal norms and the law. Symptoms of cyber bullying are seen to be a widespread trend nowadays and if not curbed, can lead to serious repercussions on society. Women are seen to be the main target of these symptoms compared to men as well as affecting their psychological well-being. This risk has the potential to increase due to the increasing need for internet access during the period of enforcement of the Movement Control Order (MCO). Thus, exposure to the rights as users of social media as well as the assistance of appropriate support systems should be provided to protect them from being exposed as victims of this crime. Social media platforms should be a safe field of interaction and free from any threats, harassment and invasion of privacy of any party. Therefore, each party must take the initiative to create a harmonious digital ecosystem through self-control in the use of social media.

\section{Acknowledgments}

This paper is one of the research output made for fulfilling the Incentive Research Grant (Kolej Universiti Islam Melaka) requirement under the project entitled, 'The Influence of ICT Accessibility on Cyber Bullying: A Study Among Melaka Youth' numbered GPI/21/F1/18

\section{References}

Alim, S. (2017). Cyberbullying in The World Of Teenagers And Social Media: A Literature Review. In Information Resources Management Association, Gaming and Technology Addiction: Breakthroughs in Research and Practice, 520-552.

Ansong, E. D. Tony, T., Dominic, D., Ampomah, E. A., \& Larkotey, W. (2013). Internet Trolling in Ghana. International Journal of Emerging Science and Engineering, 2(1), 42-43.

Astro Awani. (2019). MCMC Perlu Diberi Kuasa Padam Berita Palsu, Fitnah Serta Perkauman, https://www.astroawani.com/berita-malaysia/mcmc-perlu-diberi-kuasa-padam-beritapalsu-fitnah-serta-perkauman-200518, dicapai pada 12 September 2020.

Berita Haria.n (2020). COVID-19: Pesakit trauma akibat cemuhan netizen, https://www. bharian.com.my/berita/nasional/2020/04/682940/covid-19-pesakit-trauma-akibatcemuhan-netizen, dicapai pada 17 September 2020.

Berita Harian. (2018). Ancaman Buli Siber, https://www.bharian.com.my/berita/nasional/2018/01/370155/ancaman-buli-siber, dicapai pada 17 September 2020.

Bernama. (2019). Buli Siber Perlu Ditangani Segera. https://www.bernama.com/bm/news.php?id=1791049, dicapai pada 17 September 2020.

Noh, C. H. C., Ibrahim, M, Y., \& Yusooff, F. (2018). Meneroka Ciri dan Faktor Buli Siber dalam Kalangan Remaja di Malaysia. Terengganu: Penerbit UMT. 
Griffiths, M.D. (2014). Adolescent Trolling In Online Environment: A Brief Overview. Education and Health Journal, 32(3), 85-87.

Harian Metro. (2020). Mangsa Buli Siber Boleh Bertukar Jadi Pembuli. https://www.hmetro.com.my/mutakhir/2020/05/575040/mangsa-buli-siber-bolehbertukar-jadi-pembuli, dicapai pada 17 September 2020.

IPPBM. (2017). Buli Siber dalam Kalangan Remaja di Malaysia. https://www.ippbm.gov.my/jdownloads/Infografik\%20penyelidikan/Buli\%20Siber\%20D alam\%20Kalangan\%20Belia\%20Malaysia.pdf

Morissey, L. (2010). Trolling Is A Art: Towards A Schematic Classification Of Intention In Internet Trolling. Griffith Working Papers in Pragmatics and Intercultural Communication, 3(2), 75-82.

O’Neill, M., Calder, A., \& Allen, B. (2014). Tall Poppies: Bullying Behaviors Faced By Australian High-Performance School-Age Athletes. Journal of School Violence, 13(2), 210--227.

Cohen-Almagor, R. (2018), Social responsibility on the Internet: Addressing the challenge of cyberbullying, Aggression and Violent Behavior, 39, 42-52.

Ruiz, R. M. N. M. (2019). Curbing Cyberbullying among Students: A Comparative Analysis of Existing Law among Selected Asean Countries. PEOPLE: International Journal of Social Science, 4(3), 1285-1305. 